\title{
Utilization of Pantawid Pamilyang Pilipino Program (4PS) Financial Aide and Pupils' Academic Performance
}

\author{
Ailene O. Basco, Carolyn M. Illescas, Sharon Rose Bontongon \\ Western Philippines University, Philippines
}

\begin{abstract}
:
EXECUTIVE SUMMARY:

This study was conducted to assess awareness on the utilization of Pantawid Pamilyang Pilipino Program (4Ps) in Education of Sta. Monica Elementary School and MatahimikBucana Elementary Schools of District II, City Division of Puerto Princesa as reflected in Pupils' academic performance. There were 153 respondents in this study.
\end{abstract}

The descriptive-correlation research design was used in the study. Data were gathered through questionnaires while frequency, percentage, mean and Pearson Moment Correlation Coefficient $r$ were the statistical tools used to analyze the data.

Greater in number are the recipients who claimed that the school is 0.7-0.9 kilometres away from their home. Majority of the recipients claimed that they complied the $85 \%$ of attendance in school.

Majority of the beneficiaries have an income between (P1001-P3000) and most of them are high school graduate.

The level of academic performance of the recipients of Pantawid Pamilyang Pilipino Program (4Ps) is satisfactory.

Beneficiaries are aware of the Pantawid Pamilyang Pilipino Program (4Ps). They always use their allowance in education according to its intended purpose.

The level of the awareness of parents/beneficiaries on the utilization of 4Ps allowance has no significant relationship to the academic performance of $4 \mathrm{Ps}$ recipients.

Keywords: beneficiaries, recipients, awareness, utilization, academic performance

Research Design: A Quantitative Research utilizing descriptive correlational design

Sampling: Random Sampling

Data Collection: Research- made Questionnaire

Data Analysis: Slovin's formula, Pearson Product Moment Correlation Coefficient r, weighted mean, frequency counts, percentages and rank

\section{INTRODUCTION AND RATIONALE}

$\mathrm{T}$ he Pantawid Pamilyang Pilipino Program (4Ps) that was created by the former president Gloria Macapagal-Arroyo is a poverty reduction strategy that provides grants to extremely poor households to improve their health, nutrition and education particularly of children aged $0-14$ by providing incentives for poor families to invest in their future by ensuring that mothers and children can avail the free healthcare as well as the free education for children. As such, it is a human development program that invests in the health and education of children. It aims to provide monetary aid to poor beneficiaries with the hope that these investments in human capital would lessen the great financial divide among the haves and the have knots (Fernandez, L., \& Olfindo, R., 2011).

This strategy was created due the impact of poverty of the Filipino people. Through this, it is believed that the children, who belong to the poor family, could somehow cope up with the minimum requirements in school. The program provides beneficiaries cash grants of P500.00 a month for health and nutrition expenses and three hundred pesos (P300.00) a month per child for educational expenses. Each child will receive three thousand pesos (P3000.00) for one school year or 10 months or P300.00 / month per child for educational expenses. A maximum of three children per household is allowed. A household with three qualified children could get P1, 400.00 monthly (Department of Social Welfare and Development 2012)

The researchers would like to find out the proper utilization of 4Ps financial aid and pupils'academic performance of Sta. Monica Elementary School and Matahimik-

Bucana Elementary School of Puerto Princesa District II. The researchers would like to find out if the recipients are only complying the $85 \%$ attendance without prioritizing their academic performance. This research was conducted to validate the claim that there is no significant relationship between the level of awareness of 4Ps beneficiaries in terms of utilization of allowance and the academic performance of the 4Ps recipients (Basco 2016). This research will help the researchers to further understand the importance of Pantawid Pamilyang Pilipino Program in the improvement of the academic performance of the recipients. This will also enlighten the beneficiaries on the awareness of the proper utilization of the 4Ps financial aide for the education of their children. The researchers also believed that through this study 
they can contribute valid and reliable findings for the future researchers and help their beneficiaries as well in the awareness of the program.

\section{RESEARCH METHODOLOGY}

\section{A. Design}

The descriptive correlation research design was used in the study. Descriptive design was used to describe the level of awareness of the beneficiaries towards 4Ps Program in Education, and how the parents utilized the 4Ps allowance in education.

On the other hand, correlation research was used to analyze the relationship between the 4Ps program in education and the recipients'academic performance in school.

\section{B. Sampling}

The researchers used stratified random sampling and Slovin's formula to determine the number of respondents in different selected 4Ps beneficiaries of Sta. Monica Elementary School and Matahimik- Bucana Elementary School of Puerto Princesa District II.

One hundred fifty-three (153) 4Ps recipients and beneficiaries were involved in this research.

The self-formulated survey questionnaire was used, which was composed of three (3) parts; Part I-Survey questionnaire on the Profile of the recipients and beneficiaries, Part II is the questionnaire about the level of awareness of 4Ps benificiaries in terms of their utilization of allowances. Further, in assessing the 4Ps recipients' academic performance, the general average during first grading period of school year 2018-2019 has been used.

\section{Data Collection}

The researchers personally administered the research instruments to the respondents as identified, based on the sampling procedure. The researchers explained further to the respondents how to answer the instrument. Directions were carefully followed by them as explained for clarification. The respondents were assured that their responses will be confidential.

\section{Ethical Issues}

The researchers, through the recommendation of the research division personnel secured a written permission from the City Schools Division Superintendent, District Supervisors, respective school administrators, teachers, parents and pupils to conduct the research.

\section{E. Data Analysis}

This study used different statistical tools to analyze and interpret the data. The study is descriptive in nature thus it analyzed through descriptive measures such as weighted mean, frequency counts, percentages and rank.

To describe the level of awareness of the beneficiaries in terms of their utilization of allowances towards 4Ps Program in Education, and how the beneficiaries utilized the allowances in education, the frequency counts, means, weighted means and rank were computed.

To test the significant relationship between the 4Ps in Education as correlates to selected variables, the Pearson Product Moment Correlation Coefficient $r$ correlation was utilized at 0.05 confidence level.

Data were gathered using 5-point Likert Scale in determining the level of awareness in terms of their utilization of allowances of the beneficiaries towards 4Ps Program in Education in Part II survey questionnaire.

\begin{tabular}{|c|c|c|c|}
\hline $\begin{array}{c}\text { Numerical } \\
\text { Rating }\end{array}$ & Range & Response & Descriptive \\
\hline $\mathbf{1}$ & $4.51-5.00$ & $\begin{array}{c}\text { Very much } \\
\text { aware }\end{array}$ & $\begin{array}{c}\text { Very Highly } \\
\text { Effective }\end{array}$ \\
\hline $\mathbf{2}$ & $3.51-4.50$ & Much aware & $\begin{array}{c}\text { Highly } \\
\text { effective }\end{array}$ \\
\hline $\mathbf{3}$ & $2.51-3.50$ & Aware & $\begin{array}{c}\text { Moderately } \\
\text { effective }\end{array}$ \\
\hline $\mathbf{4}$ & $1.51-2.50$ & Less Aware & $\begin{array}{c}\text { Fairly } \\
\text { effective }\end{array}$ \\
\hline $\mathbf{5}$ & $1.00-1.50$ & Unaware & $\begin{array}{c}\text { Low } \\
\text { effectiveness }\end{array}$ \\
\hline
\end{tabular}

\section{RESULTS AND DISCUSSION}

The following discussions provided answers to the aforementioned questions.

Problem 1: What describes the 4Ps recipients in terms of:

a. distance of house to school

b. attendance in school?

Table 1 provides data regarding the distance of house to school and attendance in school.

\begin{tabular}{|c|c|c|}
\hline Profile & $\begin{array}{c}\text { Frequency } \\
\text { N=153 }\end{array}$ & Percentage \\
\hline Attendance in & & \\
school & 4 & $\mathbf{2 . 6 1}$ \\
$30-32$ & 2 & $\mathbf{1 . 3 1}$ \\
$33-35$ & 3 & $\mathbf{1 . 9 6}$ \\
$36-38$ & 43 & $\mathbf{2 8 . 1}$ \\
$39-41$ & 26 & $\mathbf{1 6 . 9 9}$ \\
$42-44$ & 55 & $\mathbf{3 5 . 9 5}$ \\
$45-47$ & 20 & $\mathbf{1 3 . 0 7}$ \\
$48-50$ & & \\
Distance of school & & \\
from residence in & & \\
kilometres & 10 & $\mathbf{6 . 5 4}$ \\
$0.1-0.3$ & 25 & $\mathbf{1 6 . 3 4}$ \\
$0.4-0.6$ & 30 & $\mathbf{1 9 . 6 1}$ \\
$0.7-0.9$ & 29 & $\mathbf{1 8 . 9 5}$ \\
$1.0-1.2$ & 17 & $\mathbf{1 1 . 1 1}$ \\
$1.3-1.5$ & 25 & $\mathbf{1 6 . 3 4}$ \\
$1.6-1.8$ & 11 & $\mathbf{7 . 1 9}$ \\
$1.9-2.0$ & 6 & $\mathbf{3 . 2 7}$ \\
$2.1-2.3$ & \\
\hline
\end{tabular}


In terms of attendance in school, out of forty eight (48) of total number school days during first grading period, majority of the recipients (144 or $94.12 \%$ ) meet the condition given by the Pantawid Pamilyang Pilipino Program (4Ps) that every recipient must comply $85 \%$ or at least $85 \%$ of attendance in school. Nine (9 ) or 5.88\% did not meet the condition given by the program.

Accordingly, greater in number are the recipients $(30$ or $19.61 \%$ ) who claimed that the school is $0.7-0.9 \mathrm{~km}$. away from their home.

\section{Problem 2: What describes the 4Ps beneficiaries in terms of?}

a. monthly income

b. education attainment?

Table 2. Frequency Distribution on the Profile of Beneficiaries

\begin{tabular}{|c|c|c|}
\hline Profile & $\begin{array}{c}\text { Frequency } \\
\text { N=153 }\end{array}$ & Percentage \\
\hline Monthly income & 35 & $\mathbf{2 2 . 8 8}$ \\
Greater than 4500 & 31 & $\mathbf{2 0 . 2 6}$ \\
$3001-4500$ & 65 & $\mathbf{4 2 . 4 8}$ \\
1001-3000 & 22 & $\mathbf{1 4 . 3 8}$ \\
Less than 1000 & & \\
Highest educational & 10 & $\mathbf{6 . 5 3 8}$ \\
attainment & 5 & $\mathbf{3 . 2 6 8}$ \\
technical/vocational graduate & 12 & $\mathbf{7 . 8 4 3}$ \\
college graduate & 55 & $\mathbf{3 5 . 9 5}$ \\
college level & 35 & $\mathbf{2 2 . 8 8}$ \\
high school graduate & 19 & $\mathbf{1 2 . 4 2}$ \\
high school level & 14 & $\mathbf{9 . 1 5}$ \\
elementary graduate & 3 & $\mathbf{1 . 9 6 1}$ \\
elementary level & \\
no formal education & &
\end{tabular}

Majority of the beneficiaries (65 or 42.48\%) have an income between P1001-3000. Only twenty two or $14.38 \%$ has an income of less than P1000.00. One of the qualifications of the beneficiaries in 4Ps is that belong to families with low incomes. Based on the results, most of the 4Ps beneficiaries were earning above the required monthly income (P830.00 for extremely poor and P1,242.00 for poor). It also implies that most of the beneficiaries were overqualified to be the beneficiaries of 4Ps.

3. What is the level of awareness of the parents of the 4Ps beneficiaries in terms of their utilization of allowances?

Table 3. Level of Awareness of Parents of the 4Ps beneficiaries in terms of their utilization of allowances $=(153)$

\begin{tabular}{|l|l|l|}
\hline MGA PAHAYAG & Mean & $\begin{array}{l}\text { Descriptive } \\
\text { interpretation }\end{array}$ \\
\hline $\begin{array}{l}\text { Ang Pantawid Pamilya Pilipino Program(4Ps) ay } \\
\text { isang programa para sa mga mahihirap na pamilya } \\
\text { upang ang kanilang mga anak ay makapagkamit ng } \\
\text { libreng edukasyon. }\end{array}$ & 3.86 & Much Aware \\
\hline $\begin{array}{l}\text { Ang Pantawid Pamilya Pilipino Program ay } \\
\text { nagbibigay ng tatlong daang piso(P300) sa isang } \\
\text { buwan sa bawat bata upang panggastos sa mga } \\
\text { bayarin sa paaralan tulad ng napagkasunduan ng }\end{array}$ & 3.95 & Much Aware \\
$\begin{array}{l}\text { Samahan ng mga Magulang at mga Guro (PTA), } \\
\text { mga proyektong itinakda ng guro at mga } \\
\text { kagamitan sa paaralan. }\end{array}$ & & \\
\hline $\begin{array}{l}\text { Ibinibigay ang insentibo o halagang tatlong daang } \\
\text { piso(P300) sa kondisyon na magpapatala ang mga }\end{array}$ & 4.05 & Much Aware \\
\hline
\end{tabular}

\begin{tabular}{|c|c|c|}
\hline $\begin{array}{l}\text { Ang lahat ng mga anak ng benepisaryo mula } 3-14 \\
\text { na taong gulang na anak ng benepisyaryo ay dapat } \\
\text { nakapagpatala o nakaenrol sa paaralan. }\end{array}$ & 4.23 & Much Aware \\
\hline $\begin{array}{l}\text { Dapat makakuha ang mga mag-aaral na anak ng } \\
\text { benepisyaryo ang walumpu't limang porsyento } \\
(85 \% \text { )ng pagdalo o atendans sa loob ng isang } \\
\text { buwan sa paaralan o ang mga bata na anim } \\
\text { hanggang labing-apat na taong gulang( } 6-14 \text { )ay } \\
\text { dapat na dumalo sa mga klase nang hindi bababa sa } \\
\text { walumpu't limang porsyento }(85 \%) \text { o apat(4) na } \\
\text { araw sa isang linggo. }\end{array}$ & 4.45 & Much Aware \\
\hline $\begin{array}{l}\text { Kailangang sumunod ang mga benepisyaryo sa } \\
\text { mga kondisyong ibinigay o itinalaga ng programa } \\
\text { upang makuha ang insentibo/allowance sa } \\
\text { edukasyon. }\end{array}$ & 4.27 & Much Aware \\
\hline $\begin{array}{l}\text { Ang Pantawid Pamilya Pilipino Program( 4Ps) ay } \\
\text { tumutulong upang mapagbuti ang pagganap sa } \\
\text { paaralan. }\end{array}$ & 3.45 & Much Aware \\
\hline $\begin{array}{l}\text { Ang Pantawid Pamilya Pilipino Program( } 4 \mathrm{Ps}) \\
\text { bilang isang puhunan ng tao ay nagbabawas ng } \\
\text { malaking pagkakaiba pagdating sa pinansiyal na } \\
\text { usapin sa pagitan ng mga taong hirap sa buhay at } \\
\text { ang mayroon sa buhay sa larangan ng edukasyon. }\end{array}$ & 3.27 & Aware \\
\hline $\begin{array}{l}\text { Ang Pantawid Pamilya Pilipino Program (4Ps) ay } \\
\text { nagkakaloob ng alawans para sa pang-edukasyon } \\
\text { para sa mga materyales na kailangan para sa } \\
\text { akademya o pag-aaral. }\end{array}$ & 3.59 & Much Aware \\
\hline $\begin{array}{l}\text { Ang ipinagkakaloob na salapi (cash grant) ay } \\
\text { nakalaan para panggastos sa pag-aaral upang } \\
\text { mapabuti ang pagganap o performans ng mga anak } \\
\text { ng mga benepisyaryo sa paaralan. }\end{array}$ & 3.50 & Aware \\
\hline $\begin{array}{l}\text { Ang ipinagkakaloob na salapi (cash grant) para sa } \\
\text { edukasyon ng programa ay maaaring magamit sa } \\
\text { iba pang mga gastusin sa bahay. }\end{array}$ & 2.95 & Aware \\
\hline 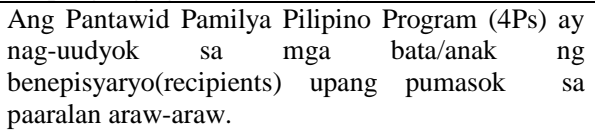 & 3.59 & Much Aware \\
\hline $\begin{array}{l}\text { Ang Pantawid Pamilya Pilipino Program (4Ps) ay } \\
\text { tumutulong upang mapabuti ang marka o } \\
\text { akademikong pagganap sa paaralan ng mga anak ng } \\
\text { benepisyaryo. }\end{array}$ & 3.00 & Aware \\
\hline $\begin{array}{l}\text { Ang Pantawid Pamilya Pilipino Program (4Ps) ay } \\
\text { tumutulong upang makabili ng mga kagamitan at } \\
\text { iba pang mga pangangailangan sa paaralan. }\end{array}$ & 3.32 & Aware \\
\hline $\begin{array}{l}\text { Ang Pantawid Pamilya Pilipino Program (4Ps) ay } \\
\text { tumutulong upang matugunan ang kanilang mga } \\
\text { pinansiyal na pangangailangan sa paaralan. }\end{array}$ & 3.23 & Aware \\
\hline $\begin{array}{l}\text { Ang Pantawid Pamilya Pilipino Program (4Ps) ay } \\
\text { tumutulong upang madagdagan ang kagustuhan sa } \\
\text { pagdalo sa paaralan (attendance rate) ng mga anak } \\
\text { ng benepisyaryo. }\end{array}$ & 3.45 & Aware \\
\hline $\begin{array}{l}\text { Ang mga magulang ng mga mag-aaral sa ilalim ng } \\
\text { program ng 4Ps ay aktibong nagbabayad ng } \\
\text { kontribusyon paaralan. }\end{array}$ & 2.77 & Aware \\
\hline $\begin{array}{l}\text { Ang mga magulang } / \text { benepisyaryo ay } \\
\text { sumusuporta sa mga mag-aaral/anak sa paggawa } \\
\text { ng proyekto at sumusunod sa mga pinag-uutos ng } \\
\text { paaralan. }\end{array}$ & 3.00 & Aware \\
\hline $\begin{array}{l}\text { Ang mga anak ng benepisyaryo/ mag-aaral ay may } \\
\text { sapat na "baon". }\end{array}$ & 2.95 & Aware \\
\hline $\begin{array}{l}\text { Ang mga anak ng benepisyaryo / mag-aaral ay } \\
\text { hindi nagrereklamo tungkol sa kanilang mga } \\
\text { pagkain o hindi nagugutom. }\end{array}$ & 2.95 & Aware \\
\hline $\begin{array}{l}\text { Ang mga anak ng benepisyaryo ay sabik na matuto, } \\
\text { aktibo sa klase, at aktibong lumalahok sa bawat } \\
\text { gawain sa paaralan. }\end{array}$ & 2.91 & Aware \\
\hline Mean & 3.47 & Aware \\
\hline
\end{tabular}


Table 3 presents the level of awareness of parents of the 4Ps recipients in terms of their utilization of allowances. The statement "Dapat makakuha ang mga mag-aaral na anak ng benepisyaryo ang walumpu't limang porsyento ( $85 \%$ )ng pagdalo o atendans sa loob ng isang buwan sa paaralan o ang mga bata na anim hanggang labing-apat na taong gulang( 614 )ay dapat na dumalo sa mga klase nang hindi bababa sa walumpu't limang porsyento(85\% ) o apat(4) na araw sa isang lingo" got the highest mean of 4.45 followed by "Kailangang sumunod ang mga benepisyaryo sa mga kondisyong ibinigay o itinalaga ng programa upang makuha ang insentibo/allowance sa edukasyon." with a mean of 4.27. The least mean of 2.71 went to "Ang mga magulang ng mga mag-aaral sa ilalim ng program ng 4Ps ay aktibong nagbabayad ng kontribusyon sa paaralan.”

The over-all mean of 3.47 , implies that beneficiaries are often aware in the monitoring and utilization of 4Ps allowance in education. Some of the beneficiaries used the allowance in education in an intended purpose but sometimes they used it in other needs of the family which is not seen by the social workers. Maybe the social workers should have close monitoring on how the beneficiaries utilized the allowance in education.

4. What describes the academic performance of the selected 4Ps recipients of Sta. Monica Elementary School and Matahimik-Bucana Elementary School in terms of general average in all subjects during the first grading period school year 2018-2019?

Table 4. Level of Academic Performance of the Recipients During the First Grading Period School Year 2018-2019

\begin{tabular}{|c|c|c|c|}
\hline Score & $\begin{array}{c}\text { Descriptive } \\
\text { Interpretation }\end{array}$ & $\begin{array}{c}\text { Frequency } \\
\mathrm{N}=153\end{array}$ & Percentage \\
\hline $90-100$ & Outstanding & $\mathbf{0}$ & 0 \\
$85-89$ & Very Satisfactory & $\mathbf{5 8}$ & 37.91 \\
$80-84$ & Satisfactory & $\mathbf{4 8}$ & 31.37 \\
$75-79$ & Fairly Satisfactory & $\mathbf{4 4}$ & 28.76 \\
Below 75 & Did Not Meet & $\mathbf{3}$ & 2 \\
\hline Expectations & \multicolumn{3}{|c|}{81.79} \\
Mean & \multicolumn{2}{|c|}{3.95} \\
Standard Deviation & \multicolumn{3}{|c}{88} \\
Minimum & \multicolumn{3}{|c|}{ Satisfactory } \\
Maximum & \multicolumn{3}{|c}{} \\
Level of & \multicolumn{3}{|c}{} \\
Performance & \multicolumn{3}{c}{} \\
\hline
\end{tabular}

Table 4 shows the level of academic performance of 4Ps recipients.

Majority of the recipients (58 or $37.91 \%$ ) have a grade of $85-89 \%$ which is very satisfactory level of academic performance. Forty-eight or $31.37 \%$ have a satisfactory level of academic performance with a grade belonging to $80-84 \%$. Only three (3) of recipients did not meet expectations of academic performance with the grade belonging to the grade bracket of below $75 \%$. This implies that the 4Ps recipients should also prioritize their academic performance.

The over-all mean of 81.79 , implies that Pantawid Pamilya Pilipino Program (4Ps) recipients' level of academic performance is satisfactory. The result claimed that majority of the recipients are attending school just to comply the required eighty-five percent of attendance in school but they are not actually performing well in academics.

The finding that three recipients did not meet expectations or their average grade is below $75 \%$ which negate to the suggestion that 4Ps recipients should have an average grade of $75 \%$ which is fairly satisfactory in the Congress on 4P's Program: School Based Implementation (2014).

However, Fiszbein and Schady (2009) suggest that in assessing whether or not to send their children to school in response to a Conditional Cash Transfer Program (CCT) or Pantawid Pamilya Pilipino Program (4Ps), parents take into account the quality of schooling. That is, parents enrol their children in school not only to meet the condition of the program but to have quality grades in school.

5. Is there any significant relationship between the level of awareness of the parents on the utilizations of 4Ps allowance and the academic performance of learners during the first grading period?

Table 5. Pearson Moment Correlation Coefficient $r$ showing the relationship between the level of awareness of the parents/beneficiaries in terms of the utilizations of 4Ps allowance and the academic performance of learners during the first grading period.

\begin{tabular}{|c|c|c|c|}
\hline $\begin{array}{c}\text { Number of } \\
\text { Respondents }\end{array}$ & Pearson r & P Value & Decision \\
\hline 153 & -.024 & .765 & Ho: accept \\
\hline
\end{tabular}

The degree of relationship is negatively very low using $\mathrm{P}$ value, since the $\mathrm{P}$ value is equal to .765 that is greater than the level of significance at $\alpha=0.01$. The null hypothesis is accepted. This implies that the level of awareness of parents on the utilization of 4Ps allowance is not significantly correlated to academic performance of learners during the first grading period. Once a beneficiary becomes a member of the program, educated or uneducated members are all aware of the program since there was an orientation given by a social worker.

6. Based on the findings of the study, what inputs can be proposed for the parent development session?

\section{SUMMARY OF FINDINGS, CONCLUSIONS AND RECOMMENDATIONS, SUMMARY, CONCLUSIONS AND RECOMMENDATIONS}

This chapter presents the summary, conclusions and recommendations of the study.

\section{Summary of Findings}

Greater in number are the recipients who claimed that the school is 0.7-0.9 kilometers away from their home.

Majority of the beneficiaries have an income less than P1001-3,000. Only eleven has an income of less than 
P1000.00. In terms of highest educational attainment, majority of the beneficiaries were high school graduates.

The study revealed that recipients' level of academic performance is satisfactory.

Findings revealed that the beneficiaries are aware the program and they agree on the on the monitoring and utilization of allowance.

Based on the result, beneficiaries always used the allowance in education according to its intended purpose. They always pay school fees regularly when they receive the allowance in education as well as they always provide their children with educational materials.

Results also revealed that awareness of parents on the utilization of 4P's allowance have no significant relationship in the academic performance of the recipients.

\section{Conclusions}

Based on the significant findings of this study the following conclusions were drawn:

1. The Pantawid Pamilyang Pilipino Program (4Ps) in education helps to increase the attendance rate of the recipients.

2. Most of the 4Ps beneficiaries were earning above the required monthly income.

3. Some of the beneficiaries used the allowance in education in an intended purpose but sometimes they used it in other needs of the family which is not seen by the social workers

4. The recipients are attending school just to comply the required eighty-five percent of attendance in school but they are not actually performing well in academics

5. The beneficiaries' awareness of the parents on the utilization of 4P's allowance does not affect the academic performance of the recipients.

\section{Recommendations}

The researchers recommend the following:

For the School Administrators, they shouldadopt the recommended 4Ps development plan.

For class advisers, they should organize a meeting or family day session with 4Ps parents/beneficiaries to provide venue for inquiries and clarification as well as encourage the attendance and performance of the recipients/pupils in school.

For Department of Social Welfare and Development, they should have proper monitoring/close monitoring with DSWD multilink at field and offices.Social workers should frequently monitor the pupils/recipients' attendance and academic performance and coordinate with classroom advisers and provide them a copy of recipients under 4Ps for smooth monitoring. Department of Social
Welfare and Development should monitor 4Ps parents/beneficiaries leaders per barangay for coordination.

For the parents, they should use the 4Ps allowance in the education of their children according to its intended purpose and encourage their children to go to school not only to comply with the condition in the program but also to improve their academic performance.

For the community or stakeholders, they should conduct a school roll-out about the 4Ps program and seek assistance from municipal link if possible and provide assistance from Parents-Teachers Association officials regarding involvement of 4Ps parents/beneficiaries on schoolcommunity related program. 